\title{
The evolution of the positions on social issues of major political parties in Poland. Comparative analysis of the election programs of Platforma Obywatelska (Civic Platform) and Prawo i Sprawiedliwość (Law and Justice) from 2007, 2011 and 2015
}

\begin{abstract}
For many years after 1989, in the Polish socio-political discourse, the issues related to social policy were subordinated to economic matters, in accordance with the assumption that the construction of a stable market system is a priority for Polish transformations. High unemployment rate, growing poverty of Polish families, demographic collapse, and finally the global economic crisis of 2008, prompted the most important actors of political life to pay attention to social policy and to include discussions about its desired shape to the electoral agenda. The aim of the article is to characterize and analyze the evolution of positions on social issues of the largest political parties, i.e. Prawo i Sprawiedliwość and Platforma Obywatelska based on their electoral programs in 2007, 2011 and 2015.
\end{abstract}

Key words: social policy, electoral program, political party, social policy model

\section{Introduction}

S ocial policy, as a public policy, is a field not only of political disputes over its individual solutions, but also of electoral competition. In Poland, after social issues were marginalized in the 1990s and the beginning of the 21 st century (See: S. Golinowska, 2018, pp. 103-137), the discussion on the desired model and the direction of individual solutions and the priorities of social policy has come to the forefront of the political debate.

The aim of the article is to characterize the evolution of the importance of social issues as a component of the election programs of the largest political parties, i.e. Civic Platform (Plartforma Obywatelska, PO) and Law and Justice (Prawo i Sprawiedliwość, PiS) ${ }^{1}$ between 2007 and 2015. This allowed the following research hypothesis to be formulated: the political parties dominating the Polish scene are giving more and more attention to social issues, which is reflected in their election programs.

Both the aim of this article and the hypothesis presented determined the choice of the research method. It was assumed that a comparative analysis would be the most optimal method, which allows the comparison of specific phenomena over time and specific entities at a given time to be made. Both options will be used in this article.

Two entities were selected for analysis, i.e. the election programs of the two largest parties on the Polish political scene, and three moments in time, namely the years of the

1 The official translation of the names of political parties in Poland: https://www.europeansocialsurvey.org/docs/round8/survey/ESS8_appendix_a3_e02_1.pdf, DOA: 18.06.2019. 
subsequent election campaigns to the Polish parliament - Sejm - 2007, 2011 and 2015. The concept of the research process thus outlined made it possible to:

- determine the place of social issues in the structure of the election programs of both parties in individual years;

- identify the changes that took place in the approach of both parties to social issues depending on the year of the campaign;

- present general characteristics of the social model preferred by both parties and an assessment of whether these preferences changed depending on the year of the campaign, which in turn allowed the research hypothesis set out in the introduction to be verified.

\section{Elections in $\mathbf{2 0 0 7}$}

When the 2007 election campaign began the economic situation was good but the socio-political relations were tense in Poland (More in: Sokołowski, 2015, pp. 118-121). The favorable global economic situation in 2005-2007 and the continuation of the liberal economic policy ${ }^{2}$ of the previous governments of the coalition government of Law and Justice, Self-Defense and the League of Polish Families had all translated into the good condition of the Polish economy at that time. This was mainly demonstrated by high economic growth $(3.6 \%$ in $2005,6.1 \%$ in 2006 , and $6.6 \%$ in 2007), a drop in unemployment rate to $10.1 \%$ (compared to $17.6 \%$ in 2005 , and $14.8 \%$ in 2006) and an increase in employment rate to $57 \%$ (Stolarska, 2008, p. 175).

This favorable economic situation did not fundamentally affect the political atmosphere which was very tense. One source of the tension was the intensifying conflict between the two largest parties (one in power, the other one in opposition), even though they had previously announced the willingness to create a coalition (as early as in 2005) (Markowski, 2008, p. 817). The other one was the governing style of the ruling coalition. Following the slogans of moral renewal, greater concern with ordinary people and fighting against the elites forming a system of interrelationships that gave them an advantage over the rest of society, Law and Justice in coalition with the populist parties, became embroiled in a series of conflicts. ${ }^{3}$ In their attempts to solve them the party was accused of allegedly using special services for their own political interests. ${ }^{4}$ The turbulent col-

2 This policy was promoted by Prof. Zyta Gilowska, formerly an influential member of Civic Platform, and the Minister of Finance in the government of Law and Justice in 2005-2007. Her flagship reforms, i.e. lowering of tax rates (from 19,30 and $40 \%$ to 18 and $32 \%$ ), reduction of disability insurance contributions (both on the employee and employer side), liquidation of inheritance tax for the immediate family, were all contrary to declarations of Law and Justice in the 2005 and 2007 campaigns, and much closer to the idea of a 'liberal Poland' rather than a 'solidary Poland' (See: Baran, Suwalski, 2016; Fedoruk, 2016).

${ }^{3}$ It suffices to recall the conflict with the medical community over 'the case of Doctor G.,' with the military community over the reasons for and the method and consequences of the dissolution of the Military Information Services, or the academic one, the source of which was the Lustration Act (See: e.g. Zamana, 2016, p. 205).

${ }^{4}$ This was the assessment of the prosecutor's office headed by Zbigniew Ziobro and the CBA headed by Mariusz Kamiński in the cases of the land-deal scandal, 'the case of Doctor G.', Barbara Blida's suicide, and the provocation against Beata Sawicka (See: Dudek, 2013, pp. 578-590, 597). 
lapse of the coalition and the dissolution of Sejm in 2007 created the image of Law and Justice as an unpredictable party, prone to extreme actions, disloyal to its partners, and thus unable to form coalitions.

The above-mentioned circumstances had an impact on the election programs prepared by the two largest parties, namely Civic Platform and Law and Justice, for the 2007 campaign.

Civic Platform entitled its quite extensive (92-page) election program Poland deserves an economic miracle (Pl. Polska zastuguje na cud gospodarczy) and promoted it with the slogan: "Let life be better. For all" (Pl. "By żyło się lepiej. Wszystkim"). In the introduction, Donald Tusk, the chairman of Civic Platform, proposed to conclude a pact for the "National Great Construction Program" (Pl. "paktu na rzecz Narodowego Programu Wielkiej Budowy"), in order to emphasize the construction of motorways, expressways, bridges, viaducts, flats and stadiums, rather than "quarrels, turmoil and an Eastern European model of democracy" (By żyto się lepiej, 2007, p. 4), which was a direct reference to the two-year rule of Law and Justice and its coalition partners. Thus, the priorities of the potential future government of this party were outlined, which generally involved the great modernization and bringing Poland closer to the countries of the 'old' European Union in terms of infrastructure. The program was divided into 12 chapters, each corresponding to a specific sphere of public policy.

The sixth chapter, entitled Social policy: family, work, solidarity society, was devoted to social policy and was preceded by chapters outlining the vision of a limited but efficient state based on the liberal doctrine of the state as a "night watchman. ${ }^{5}$ Solutions to basic social issues were part of the same vision. They were to be implemented in accordance with the liberal model of social policy, ${ }^{6}$ since the time had come for "a fundamental reorientation: the transition from an anachronistic, inefficient welfare state never keeping up with the needs, into a model of the state focused on employment and

${ }^{5}$ This doctrine includes such postulates as (1) the reduction of bureaucracy and decentralization in accordance with the principle of subsidiarity contained in chapter 1 entitled $A$ strong, cheap and friendly state; (2) increased share of private property (including privatization of social apartments by selling them to current tenants, privatization of state property) and re-privatization discussed in chapter 3 entitled Poland caring for the freedom and security of citizens; (3) flat tax, limiting the budget deficit and public debt as a development objective, eliminating the dividend and inheritance taxes, reducing taxes for entrepreneurs, presented in chapter 4 entitled $A$ strong Poland, based on ownership and justice; (4) introducing competition in health insurance and increasing the commercialization of medical services addressed in chapter 5 entitled Healthy Poland (See: By żyto się lepiej, 2007, pp. 10-39).

${ }^{6}$ There are many typologies of social policy models. The most important among them is the EspingAndersen typology, which distinguishes three types of welfare state: liberal, conservative-corporate and social-democratic. The liberal model assumes a low income criterion for social benefits, which means that the poorest are entitled to them. The criteria for granting benefits are clearly defined, but cover a relatively small group of beneficiaries. The goal of such a policy is primarily to encourage people to seek employment and to reduce their dependence on state aid in the form of social transfers. The author refers to the Polish version: G. Esping-Andersen, Trzy światy kapitalistycznego państwa dobrobytu, trans. by K. W. Frieske, Wydawnictwo Dyfin, Warszawa 2010, pp. 44-45. The equivalent of the liberal state in other typologies of social policy commonly present in the theory of social policy is the marginal state (residual model) by R. Titmuss, or the positive state distinguished in the typology by N. Furniss and T. Tilton (See: Titmuss, 1974; Furniss, Tilton, 1977). 
cohesion [...]." ${ }^{.7}$ As part of this reorientation, the changes in social policy should be based on the following pillars.

The family, as "the most efficient social unit, caring for and supporting children, as well as the elderly, the disabled and the unemployed most efficiently," should be economically independent because of having access to education and work instead of financial benefits. To this end, the program provided for a review of family benefits (in terms of their effectiveness, addressing the needs and costs) and prioritizing those tools that promoted independence and professional activation. Such tools included extending (gradually) maternity leave to 22 weeks, promoting parental leave to be taken by both parents, popularizing part-time employment, introducing family-friendly tax breaks, supporting task-oriented programs for large families, and introducing competition on the market of care services financed by the state.

An efficient labor market that would stimulate an increase in the professional activity of Poles from $57 \%$ to $65 \%^{8}$ (in 2012). In this area, Donald Tusk's party looked for solutions primarily with reference to (a) improving employment services (e.g. by commercializing job placement services; deleting the unemployed who do not seek jobs from the unemployment register; integration of the employment and social assistance systems; adapting vocational activation tools to disfavored groups; development of the social economy sector); (b) changing the policy towards disabled people in order to activate them (e.g. by increasing their access to universities, unifying the case-law on legal disability status, changing employment subsidy principles in line with the "money follows the person" idea, decentralization of tasks implemented by the Disabled Persons' Rehabilitation Fund, PFRON); (c) development of lifelong learning; (d) reduction of labor costs, including the reduction in the number of sick days of the employee for which the employer pays; "ordering and rationalizing" social expenses, and reducing disability insurance premiums for people entering the labor market; (e) creating a Polish flexicurity ${ }^{9}$ model by promoting the effective use of flexible forms of employment provided for in the Polish law, decentralization of labor law (including the introduction of provisions enabling effective termination of collective agreements), extension of overtime calculation period from 3 to 12 months, promotion of non-standard forms of employment (telework, remote work), and the promotion of selfemployment as one of the forms of professional activity. ${ }^{10}$

${ }^{7}$ By żyło sie lepiej..., op. cit. p.40. It is rather risky to talk about Poland as the welfare state, admittedly anachronistic and inefficient, in the light of the assessments of social policy implemented by the Polish state after 1989 available in the literature on the subject (See: e.g. Golinowska, 2006, p. 22-25; Polakowski, 2012; Grewiński, 2017, pp. 59-92; Orczyk, 2012, pp. 31-41).

${ }^{8}$ Over the entire period of 2007-2019, the economic activity rate has not even come close to this level. In 2018, the average annual value of this indicator was 56.3\% (See: GUS, Podstawowe...).

9 The flexicurity model is a model of the labor market combining the needs of employers and the expectations of employees. The word flexicurity is a combination of the words flexibility and security. This is a strategy of combining flexible forms of employment with employee protection by creating the opportunity to preserve the workplace, find a new one in the shortest time possible and provide financial support during unemployment. The fexicurity model creates the golden triangle, i.e. laws making labor law more flexible, employee social security as well as educational and activating tools for job seekers. The first country to successfully apply flexicurity (having created this concept) was Denmark in the 1990s (See: Rymsza, 2005, p. 9; Rękas, 2010, p. 318; Rollnik-Sadowska, 2013, p. 39).

${ }_{10}$ Importantly, in the flexicurity model proposed by Civic Platform there is not a single security solution that increases employee protection on the labor market. 
Solidarity between generations. This point was to draw attention to the problem of low professional activity of people over 50 and high unemployment among young people, which created the risk of intergenerational tensions. The proposals for the young generation emphasized, among other things, the postulate of the education system coherently responding to the needs of the labor market, ensuring financial support for starting a business, and developing a program encouraging young people to return from emigration.

Social trust, i.e. the development of civil society. To this end, Civic Platform proposed, among other things, to increase NGOs' share in performing public services, to facilitate the creation of social partnerships, to exempt NGOs' profits from tax, and to promote voluntary service as a form of first employment (By żyło się lepiej..., 2007, pp. 40-49).

The set of solutions to basic social issues proposed by Civic Platform formed a fairly coherent system based on several basic assumptions. The first assumption was to reduce social spending and direct the money to those most in need ("ordering and rationalizing" social transfers). The next one was to acknowledge the fact that family is the best provider of protection and care (both for children and the elderly). Another one was the commercialization of public services and introducing competition between private and public entities in the implementation of social policy tasks. These assumptions, coherent with the rest of the program, created a vision of a country with a liberal economy, implementing a marginal (liberal) model of social policy, obviously adapted to the realities of Poland in 2007.

The election program of Law and Justice was a continuation of the victorious platform from 2005, ${ }^{11}$ additionally including a list of successes achieved (tasks accomplished) during the two-year rule. The 74-page program, entitled We care for Poland. We care for Poles (Pl. Dbamy o Polskę. Dbamy o Polaków), contained 7 chapters (Dbamy o Polskę..., 2007, p. 1). In the introduction, President of Law and Justice Jarosław Kaczyński clearly indicated the priorities of his future government. The first was to implement the vision of a "citizen-friendly and effective" state, which included combating crime and corruption and the continuation of the judicial reform. The second was based on the "faith in people," which meant support for the development of entrepreneurship (mainly small businesses) by reducing tax burdens. The third one, crucial for this study, was to implement the principle of state subsidiarity, ${ }^{12}$ understood as offering help "in the name of

${ }^{11}$ For the purposes of the 2005 campaign, in order to distinguish itself from Civic Platform, Law and Justice created a division between a 'solidary' and 'liberal' Poland and identified itself with the former. This solidarity, however, was primarily to strengthen the security of citizens through a firm fight against crime (24-hour courts, toughening penalties), fight against corruption, a broad vetting of people in positions of public trust and breaking up post-communist social and business systems. Thus, this solidarity had the character of restoring a sense of elementary justice in society, and was less associated with the revolution in social policy pursued by predecessors (See: Program 2005..., 2006, p. 123; Klepka, 2008, pp. 153-154; Haber, 2013, p. 221).

${ }_{12}$ Pope Pius XI is considered to be the author of the modern understanding of the principle of subsidiarity, who stated in the Encyclical Quadragesimo Anno that "that most weighty principle, which cannot be set aside or changed, remains fixed and unshaken in social philosophy: Just as it is gravely wrong to take from individuals what they can accomplish by their own initiative and industry and give it to the community, so also it is an injustice and at the same time a grave evil and disturbance of right order to assign to a greater and higher association what lesser and subordinate organizations can do. 
social solidarity" to people who "are not coping" which "will allow them to get back on their feet" (Dbamy o Polske ..., 2007, p. 1)

In accordance with the sequence outlined in the introduction to the program, the third chapter was dedicated to social policy, and was entitled Human is the most important. Importantly, however, this chapter is considerably shorter than chapter 1, entitled Administration and internal security, and chapter 2 on Economic policy. A significant part of it was devoted to the achievements of the two-year rule, which was the time of shrinking unemployment, reduced disability insurance premiums, increasing minimum wage, introducing an approximate PLN 100 tax relief for children, slightly increasing family benefits, and the introduction of becikowe (a one-time benefit payable for each child born). The new solutions Law and Justice proposed included, among other things, the following:

1) a 6-percent increase in net salaries ("in the near future");

2) extension of maternity leave to 26 weeks, and to 39 weeks in multiple pregnancy;

3) reimbursement of fees for the child's stay in kindergarten/nursery school for working parents;

4) exemption from payments to the Labor Fund and Guaranteed Employee Benefits (for 3 years) for the employers of persons returning to the labor market after maternity and parental leave;

5) tax breaks for companies establishing kindergartens;

6) enabling parents who are business owners to suspend their business activity for the duration of their childcare (up to 3 years); in this period, disability insurance premiums would be paid from the state budget;

7) tax relief (write-off of PLN 1,000) for long-term savers;

8) increase in funds for health care, ultimately to 6 percent of the GDP in 2010 (Ibid., pp. 39-47).

It is difficult to see a specific, target model of the social policy preferred by Law and Justice both in the sphere of real actions in 2005-2007, and the election declarations contained in the 2007 campaign program. While this party went to elections with a clearly outlined vision of the state in such areas as security and justice, in the social sphere it proposed ad hoc solutions in the most pressing issues of social life.

\section{Elections in 2011}

Several key events affected the 2011 campaign. The most important one was the Smolensk plane crash, which led to a new sociopolitical division in Poland and further aggravated the severe conflict between the two largest parties, while also leading to

For every social activity ought of its very nature to furnish help to the members of the body social, and never destroy and absorb them. [...] Therefore, those in power should be sure that the more perfectly a graduated order is kept among the various associations, in observance of the principle of 'subsidiary function,' the stronger social authority and effectiveness will be the happier and more prosperous the condition of the State." It has been adopted unchanged by the European Union law and the Constitution of the Republic of Poland and most fully implemented by the legal status of local government as the level of public authority that is closest to the citizens (See: Pius XI, 1982, pp. 707-708; FejaPaszkiewicz, 2008, pp. 23-29). 
a cultural conflict between their respective electorates. ${ }^{13}$ Another one was the global economic crisis of $2008,{ }^{14}$ which significantly affected the condition of the Polish economy, in particular in 2009 and 2010, as reflected in basic macroeconomic indicators declining. The crisis had a dual impact on the situation of the ruling party in the year of the election campaign. On the one hand, it was negative, because in 2011, due to the extended, excessive deficit procedure (EDP), ${ }^{15}$ Civic Platform launched a number of corrective actions ${ }^{16}$ that had an adverse impact on the material situation of potential voters. On the other one, it strengthened the image of the leaders, because Poland was one of the few countries which avoided recession and observed a positive economic growth rate despite the global crisis.

Civic Platform entitled its election program, which was even more extensive than the one from 2007, The next step. Together (Pl. Nastepny krok. Razem), and promoted it with the electoral slogan: "Poland under construction" [P1. "Polska w budowie" (Platforma Obywatelska..., 2011, pp. 9-20)]. The latter was further elaborated on in Donald Tusk's declaration opening the program, where he clearly positioned Civic Platform as the party of the ideologically indifferent center, whose main goal was to further modernize the country, stimulate the innovation and creativity of its citizens, and ensure a permanent place for Poland in the group of highly developed countries - the European Union (Ibid., pp. 1).

The program was divided into four chapters, none of which was entirely devoted to social policy. The issues of family policy and health protection were included in chapter 2, entitled Family and security, alongside such issues as foreign policy, sports and energy security, and the labor market and pension system policies in chapter 4: Stable Economy. The remaining chapters were dedicated to Innovation and social capital (chapter 1) and Free citizens and an effective state (chapter 3) (Ibid., pp. 5-6). This symbolic marginalization of social policy was reflected in the program. Civic Platform basically repeated what Law and Justice had done and devoted most of the program to the achievements from 2007-2011, and, instead of new systemic solutions, proposed only the continuation and modification of the old ones. As regards the policy of family support, it declared, among other things, the following:

13 This division assumed an exclusionary character, denying each party's legitimacy to participate in social and political life. The Smolensk division also ended the programmatic evolution of Civic Platform and Law and Justice (See: Sokołowski, 2015, p. 124; Wojciechowski, 2016, pp. 89-92).

14 The global crisis began in the United States when the speculative bubble in the real estate market had burst in 2007, which then spread (through toxic financial instruments in which European banks had invested) to Western European countries and then to other countries of the region. From the financial markets, the crisis moved to the real economy (See: NBP, 2009, pp. 4-8).

15 The excessive deficit procedure is imposed by the EU Council on a member state if it does not meet the convergence (coherence) budget criteria, which are: $3 \%$ of the actual public deficit in relation to the GDP expressed in market prices and $60 \%$ of the public debt in relation to the GDP expressed at market prices. Pursuant to the provisions of the Treaties - in order to ensure the effectiveness of the procedure applied in the event of an excessive deficit, the governments of member states are responsible for the public deficit. Member states are required to implement corrective actions to meet the convergence criteria (See: Budzyński, 2008, pp. 237-238).

${ }^{16}$ These activities included, among other things, increasing the basic VAT rate from $22 \%$ to $23 \%$ and the reduced VAT rate from $7 \%$ to $8 \%$, freezing wages in the budgetary sphere, reducing expenditure on labor market programs, reducing the pension premium transferred to OFE (Open Retirement Funds) by ZUS (Social Security Office) from 7.3\% to 2.3\% (See: Przybyciński, 2013, p. 249). 
1) a radical increase in the family-friendly tax relief starting in 2014 ("when we are no longer subject to the excessive deficit procedure");

2) leveling out the amount of subsidies for public and private kindergartens;

3) increasing the activity of the disabled on the open labor market;

4) introduction of renewable seasonal contracts into the labor code (as part of enhanced labor market flexibility);

5) radical increase in expenditure on the activation of senior citizens, ultimately up to PLN 110 million in 2014 (Ibid., pp. 99-107).

Civic Platform continued its liberal course in health policy planning to introduce private health insurance contracting healthcare services competing with the NFZ (National Health Fund) in 2013. In addition, the party promised full computerization of health care and the recognition of the qualifications of Polish nurses by European Union countries without the requirement of additional courses or studies (Ibid., pp. 116-118).

The labor market policy and social security were to be improved, among other things, by freezing wages in the budget sector, introducing provisions guaranteeing "equal pay for equal work, ${ }^{\prime 17}$ opening regulated professions, intensive privatization of enterprises supervised by the State Treasury, and tax breaks up to 6 percent of income for persons who joined the voluntary pension plans (Ibid., pp. 175-177).

What comes to the forefront when comparing the 2007 program of Civic Platform with that proposed in 2011, is that the party's most liberal ideas on the arrangement of socioeconomic relations were reviewed. The program was de-ideologized resulting in abandoning flat tax and the commercialization of public services. At the same time, the party did not decide to fundamentally reorient its approach to solving basic social issues, retaining much of its former position, namely "not disturbing" the independence of citizens.

Law and Justice, seeking a stable and distinctive place on the political scene, strengthened its conservative (right-wing) message. A long introduction to their election program entitled Modern, Solidarity, Safe Poland (Pl. Nowoczesna Solidarna Bezpieczna Pol$s k a$ ) identified the fundamental values that this party would follow. The most important among them included the nation, taking pride in being Polish, solidarity and coherence, fighting 'impossibilism' (i.e. the inability of the authorities to act effectively due to control functions of various institutions that restrained them) and the establishment, which for its own benefit blocks the development opportunities of other social groups (Nowoczesna Solidarna.., 2011, pp. 11-63). As suggested by the title of the program, it was divided into three basic blocks, of which the second one (not all of it), entitled Solidary Poland (Pl. Solidarna Polska), was devoted to social policy. The broadly understood family policy ("solidarity with families") was discussed first, which was promised to become modern and based on the culture of life, and its main goal was to improve the quality of life and economic security of families, in particular those with many children, and to create a friendly climate for parenting. This was to be achieved, among other things, by the following:

1) extension of obligatory maternity leave;

2) obligatory indexation of income thresholds for family benefits and linking them to the minimum salary;

${ }^{17}$ This is the only aspect of equality in the program of a political party that presents itself as modern and promoting modernization. 
3) introducing a "large family card" at the local government level, in close cooperation with the central government;

4) increasing the salaries of social workers;

5) launching a socio-therapeutic program at the central and local government levels;

6) amendments to the Act on Prevention of Domestic Violence to limit institutional interference in family life;

7) payment by the state budget of pension premiums for a parent caring for a disabled child who resigns from their job (Ibid., pp. 167-174).

In the field of sub-policies supporting the family policy, Law and Justice proposed developing standards for perinatal care, limiting the legal restrictions on alternative forms of pre-school education, and supporting the construction of housing for rent. The family policy framework of Law and Justice included also issues related to the care for the elderly (indicating that home care is an absolute priority for the party, while also declaring the creation of day support centers) and changes to the pension system (Ibid., pp. 175-176).

According to Law and Justice, health care was another area of social policy in need of overhaul. To improve accessibility for the patient, the party called for an extension of the responsibilities and powers of family doctors and other medical staff, the establishment of a network of hospitals (which the party considered to be the essential future reform in this area), and the reinstatement of health care financed from the budget (liquidation of the National Health Fund). In addition, the postulates included the reinstatement of school health services and encouraging enrolment in medical studies (Ibid., pp. 178-182).

In relation to the labor market, Law and Justice postulated, first and foremost, to limit the possibility of concluding multiple fixed-term employment contracts, to encourage people over 50 years of age to stay on the labor market longer, to expand the activity of public employment services and create competition for them (among other things, by equipping registered persons with an "entrepreneurship voucher" (Pl. bon przedsiębiorczości) (Ibid., pp. 185-190).

When analyzing individual elements of the social program of Law and Justice, attention should be given primarily to its internal coherence, both in terms of form (addressing important social issues in one chapter) and content (solutions close to the conservative model of social policy), and, secondly, to its ideological compliance with solutions proposed in other thematic areas.

\section{Elections in 2015}

In the second term of government, Civic Platform introduced two reforms that sparked strong social opposition. One was the reform of the pension system, which gradually extended the retirement age to 67 years for women and men. The other one lowered the age for children starting obligatory education from 7 to 6 (Marcinkiewicz, Stegmaier, 2016, p. 222). In addition, political life was shaken by the 'tape scandal' or the disclosure of recordings in which politicians of the ruling party ate octopuses in luxury restaurants, discussed private matters and the matters of the country in rough language (Szczerbiak, 
2016, p. 408). This aroused widespread indignation and created the image of Civic Platform as a party of power which is alienated and detached from the matters of ordinary people. At the same time, the biggest rival of the ruling party, Law and Justice, noticed the changing sentiments, unfulfilled aspirations and needs of many social groups, and the fatigue resulting from the reforms affecting them directly.

The same sentiments were also noticed by Civic Platform, which was reflected in its election program for the 2015 campaign, entitled Poland of the Future (Pl. Polska przyszłości). In the introduction to the program, Prime Minister Ewa Kopacz emphasized the issues that had not previously appeared in Civic Platform's programs. She said, for instance: "We know that economic growth should benefit all Polish families and help them fulfil collective hopes and individual expectations," and: "We want to enjoy not only the highways, stadiums, and university laboratories, but we also want higher wages, more stable employment conditions, and quick access to doctors" (Polska przyszłości..., 2015, pp. 5-6). The structure of the program also changed, placing such issues as economy and work, family and senior policy first, thus prioritizing social policy issues.

In matters related to the labor market, Civic Platform obliged itself, among other things, to increase the protection of persons employed under civil-law contracts ("trash contracts') by covering them with retirement and disability insurance, thereby actually changing the party's earlier decisions. The party also proposed financial support for people entering the labor market in the form of 'start-up grants' (Pl. granty na start) at the amount of PLN 4,000 annually (Ibid., pp. 9-16).

In terms of family policy, in addition to increasing the income thresholds for family benefits and increasing their amount, Civic Platform focused on improving access to childcare facilities (including incentives for employers to set them up) and increasing the availability of apartments for rent by proposing a program modeled on the experience of Housing Associations (Pl. Towarzystwo Budownictwa Społecznego - TBS) (Ibid., p. 21).

Much space in the program was devoted to senior policy, which was to demonstrate the openness of this party to addressing the demographic challenges related to the aging of the Polish society. Solutions in this area included, among other things, organization of specialized training in geriatric care for medical personnel (doctors, nurses, physiotherapists, medical caregivers), development of telemedicine, introduction of a system of incentives for entities investing in day care homes, rehabilitation centers, etc., and increasing the number of places in geriatric specializations. The issues of health care were closely linked to the senior policy in the program. In this respect, Civic Platform declared an increase in health expenditure (also by creating additional social security options), integration of the health care system with the social policy of local governments, scholarships for doctors and nurses during training on condition that they would stay in Poland for five years after its completion, and the introduction of a system for assessing the quality of medical services involving patients (Ibid., pp. 25-46).

The 2015 program of Civic Platform shifted the emphasis of its election message from liberalism and focusing on the market economy as a pillar of social well-being, to a more social-democratic one, giving more attention to social policy in its modern version, i.e. primarily the policy of developing public services available to the widest social groups possible. 
In 2015, the electoral message of Law and Justice was dominated by the promise of introducing a PLN 500.00 family allowance for each child and lowering the retirement age again to 65 for men and 60 for women. Both of these demands were included in the party's election program, which was entitled Health, Work, Family (Pl. Zdrowie Praca Rodzina). This very extensive program, with as many as 168 pages, was divided into five chapters, of which only the third one was strictly devoted to social policy. Contrary to the campaign message, it was not social transfers and specific solutions in social policy that took the most place in it, but the chapter entitled the Repairing the state ( $\mathrm{Pl}$. Naprawa państwa), which was 107 pages long (Zdrowie Praca Rodzina..., 2014). These seemingly insignificant facts, however, indicated the place of social policy in the vision of the state outlined by Law and Justice.

In addition to the two flagship social programs already mentioned, most of the solutions included in the program were the same as in 2011. The new proposals that deserve attention were the postulate to extend maternity and parental leave until the child reaches the age of six, obtaining European funds for family benefits (target financing of the ' $500+$ ' program), and raising the income threshold entitling families to family benefits to 50 percent of the minimum wage, and in the case of a family raising a disabled child to 60 percent.

The conservative model of social policy (including family policy), based on the patriarchal family model, proposed by Law and Justice in 2011, found its continuation in 2015 (Polakowski, Szelewa, Bakalarczyk, Sutowski, 2016, p. 7). It was further strengthened by the promise of this party to pay public family benefits (bez kryterium dochodowego) and ensure that children would stay outside institutional care as long as possible due to extended maternity and parental leave.

\section{Conclusions}

The analysis of the election programs of the two largest parties, which dominated the Polish political scene in 2007-2015, indicates that they significantly evolved in terms of their perception of the importance and ways of solving basic social problems in Poland.

In 2007, both Civic Platform and Law and Justice placed the main emphasis on the issues related to the functioning of the state in such areas as the economy, security, and public and government administration. Both parties devoted much less space to social policy, although it should be emphasized that it was Civic Platform that presented a program that was fairly coherent but based on a marginal model of social policy. On the other hand, Law and Justice focused on individual system deficiencies rather than comprehensive solutions to problems such as low fertility, unemployment or family poverty.

The election programs from 2011 showed, above all, the crystallization of the position of Law and Justice as to the final shape of social policy in Poland. First of all, it found a significant place in the election program, and secondly, it developed a coherent character placing itself close to the conservative model. Civic Platform was more indecisive in this area, which was reflected in the social issues chaotically scattered throughout its program and the attempts to soften the liberal message, without indicating specific solutions of a more solidary nature. 
The period of the 2015 campaign should be considered ground-breaking for both parties. The postulate of introducing a universal family benefit of PLN 500.00 made Law and Justice a pro-social party with a highly conservative character. At the same time, they launched a nationwide discussion on the priorities and directions of social policy in Poland, which made it one of the most important topics of the political and socioeconomic life. In this discussion, Civic Platform opted for a social policy model based on universally available public services, thereby approaching the social democratic model. This was reflected in the party's election program, in which the issues related to family policy, health policy or senior policy took a central place.

Considering the above, it should be concluded that the research hypothesis presented in the introduction to this article has been confirmed.

\section{Bibliography}

Baran J., Suwalski J. (2016), Z dala od równowagi - ewolucja finansów publicznych w Polsce w latach 2004-2014, „IBS Policy Paper”, no. 3.

Budzyński T. M. (2008), Procedura nadmiernego deficytu, „Annales Univeristatis Mariae CurieSkłodowska", vol. XLII, 17.

By żyło się lepiej. Wszystkim. Program wyborczy Platformy Obywatelskiej (2007), Warszawa.

Dbamy o Polskę. Dbamy o Polaków. Program wyborczy Prawa i Sprawiedliwości (2007), Warszawa.

Dudek A. (2013), Historia polityczna Polski, Kraków, pp. 578-590.

Esping-Andersen G. (2010), Trzy światy kapitalistycznego państwa dobrobytu, trans. K. W. Frieske, Wydawnictwo Dyfin, Warszawa, pp. 44-45.

European Social Survey, https://www.europeansocialsurvey.org/docs/round8/survey/ESS8_appendix_ a3_e02_1.pdf [DOA: 18.06.2019].

Fedoruk A., Co Polacy zawdzięczaja Zycie Gilowskiej?, http://biznes.onet.pl/podatki/wiadomosci/, 5.04.2016 [DOA: 18.06.2019].

Feja-Paszkiewicz A. (2008), Zasada pomocniczości a samorząd terytorialny, „Zeszyty Naukowe Publicznej Wyższej Szkoły Zawodowej im. Witelona w Legnicy", no. 4.

Furniss N., Tilton T. (1977), The Case for the Welfare State, Indiana University Press, Blomington.

Golinowska S. (2018), Modele polityki społecznej w Polsce i Europie na poczatku XXI wieku, Warszawa.

Golinowska S. (2006), Zewnętrzne uwarunkowania polityki społecznej, in: Nowe dylematy polityki społecznej, eds. S. Golinowska, M. Boni, "Raporty CASE”, no. 6.

Grewiński M. (2017), Polska polityka społeczna w latach 1989-2016 - sukcesy i niepowodzenia, in: Polityka społeczna w Polsce, eds. G. Ciury, B. Kłos, "Studia BAS”, no. 2 (50).

GUS, Informacja o sytuacji spoteczno-gospodarczej kraju. Rok 2011 (2012), Warszawa.

GUS, Podstawowe dane z Badania Aktywności Ekonomicznej Ludności wyrównane sezonowo za lata 2010-2018, https://stat.gov.pl/ [DOA: 20.06.2019].

Haber G., Polityka spoleczna, in: Kluczowe kwestie polskiej polityki. Analiza programów partii politycznych w latach 1991-2011, ed. E. Skrabacz, Torun 2013.

Klepka R. (2008), Wizje państwa w programach wyborczych z 2005 r. Platformy Obywatelskiej oraz Prawa i Sprawiedliwości, "Chorzowskie Studia Politologiczne", no. 1.

Marcinkiewicz K., Stegmaier M. (2016), The Parliamentary Election in Poland, October 2015, "Electoral Studies", vol. 41.

Markowski R. (2008), The Polish Elections of 2005: Pure Chaos or a Restructuring of the Party System?, "West European Politics", vol. 31 (5). 
NBP, Polska wobec światowego kryzysu gospodarczego, Warszawa 2009.

Nowoczesna Solidarna Bezpieczna Polska. Program Prawa i Sprawiedliwości (2011), Warszawa, pp. 11-63.

Orczyk J. (2012), Ewolucja polityki społecznej w Polsce po 1990 roku, in: Współczesne obrazy polityki społecznej i gospodarczej, eds. W. Koczur, A. Rączaszek, Katowice.

Oręziak L. (2011), Otwarte Fundusze Emerytalne -źródło dlugu publicznego, zysków dla PTE i złudzeń dla emerytów, in: Ubezpieczenie społeczne w Polsce. 10 lat reformowania, ed. J. Hrynkiewicz, Warszawa.

Pius XI (1982), Encyclical Quadragesimo Anno, “Znak”, no. 7-9.

Platforma Obywatelska, Następny krok. Razem. Program Wyborczy 2011 (2011), Warszawa, pp. 9-20;

Polakowski M. (2012), Polityka społeczna po 1989: język, kontekst, post-socjalizm i perspektywy, „Warszawskie debaty o polityce społecznej”, no. 5.

Polakowski M., Szelewa D., Bakalarczyk R., Sutowski M. (2016), Polityka społeczna rzadu Prawa i Sprawiedliwości, „Warszawskie debaty o polityce społecznej”, no. 26.

Polska przyszłości. Program Platformy Obywatelskiej RP (2015), Warszawa.

Program 2005. IV Rzeczpospolita - sprawiedliwość dla wszystkich (2006), in: Wybory 2005. Partie $i$ ich programy, eds. I. Słodkowska, M. Dołbakowska, Warszawa.

Przybyciński T. (2013), Dylematy kształtowania polityki gospodarczej i społecznej, in: Wybrane aspekty rozwoju regionalnego, eds. R. Kisiel, M. Wojarska, Olsztyn.

Rękas M. (2010), Model Flexicurity w Polsce jako odpowiedź na wyzwania wspótczesnego rynku pra$c y$, ,Ekonomia i Prawo”, vol. VI.

Rollnik-Sadowska E. (2013), Zastosowanie modelu flexicurity w polityce zatrudnienia Unii Europejskiej (ze szczególnym uwzględnieniem Polski), „Optimum. Studia Ekonomiczne”, no. 4 (64).

Rymsza M. (ed.) (2005), Elastyczny rynek pracy i bezpieczeństwo socjalne. Flexicurity po polsku?, Instytut Spraw Publicznych, Warszawa.

Sokołowski J. K. (2015), Od sojuszu do skrajnej wrogości. Ewolucja zachowań parlamentarnych Platformy Obywatelskiej i Prawa i Sprawiedliwości w latach 2001-2013, „Studia Politologica”.

Stolarska A. (2008), Wybrane elementy sytuacji spoleczno-gospodarczej Polski w latach 2000-2007 i jej regionalne zróżnicowanie, Zeszyty Naukowe SGGW w Warszawie. Problemy Rolnictwa Światowego", no. 5 (20).

Szczerbiak A. (2016), An Anti-Establishment Backlash That Shook Up the Party System? The October 2015 Polish parliamentary election, "Perspectives on European Politics and Society", vol. 18 (4).

Titmuss R. (1974), Social Policy. An Introduction, Allen and Unwin, London.

Wojciechowski Ł. (2016), Procedura wyborów do Sejmu Rzeczypospolitej Polskiej - doświadczenia z kampanii wyborczej 2011, Lublin.

Zamana J. (2016), Styl przywództwa Jarosława Kaczyńskiego. Analiza retrospektywa, "Cricital Studies", vol. 2.

Zdrowie Praca Rodzina. Program Prawa i Sprawiedliwości (2014), Warszawa.

\section{Ewolucja stanowisk w sprawach społecznych głównych partii politycznych w Polsce. Analiza porównawcza programów wyborczych Platforma Obywatelska i Prawo i Sprawiedliwość z 2007, 2011 i 2015}

\section{Streszczenie}

Przez wiele lat po 1989 r., w polskim dyskursie społeczno-politycznym kwestie związane z polityką społeczną podporządkowane były sprawom gospodarczym, zgodnie z założeniem, iż budowa 
stabilnego system rynkowego stanowi priorytet polskich przemian. Wysokie bezrobocie, rosnące ubóstwo polskich rodzin, zapaść demograficzna i wreszcie światowy kryzys gospodarczy z roku 2008, skłonił najważniejszych aktorów życia politycznego do zwrócenia uwagi na politykę społeczną i włączenia dyskusji o jej pożądanym kształcie do agendy wyborczej. Celem artykułu jest charakterystyka i analiza ewolucji stanowisk do kwestii społecznych największych partii politycznych, tj. Prawa i Sprawiedliwości oraz Platformy Obywatelskiej na podstawie ich programów wyborczych z lat 2007, 2011 i 2015.

Słowa kluczowe: polityka społeczna, program wyborczy, partia polityczna, model polityki społecznej 